\title{
SOCIAL RIGHTS BETWEEN HARD LAW AND SOFT LAW: A CASE STUDY FROM EUROPEAN UNION
}

\section{DIREITOS SOCIAIS ENTRE HARD LAW E SOFT LAW: UM CASO DE ESTUDO DA UNIÃO EUROPEIA}

JACOPO PAFFARINI

Doutor em Direito Público pela Università degli Studi di Perugia (Itália). Pos-Doutor em Direito - Faculdade Meridional (Brasil). Professor Permanente no Programa de Pós-Graduação Stricto Sensu em Direito, Faculdade Meridional - IMED. Bacharel em Direito pela Università degli Studi di Perugia. Membro pesquisador do Grupo Internacional de Pesquisa «Rights behind Bars in Europe» financiado pelo Ministério de Instrução, das Universidades e Pesquisa (Decreto Direttoriale, 25 giugno 2015 n. 1350). Colaborador assistente na Cátedra de Direito Constitucional e Direito Público Comparado, de titularidade do Prof. Dr. Maurizio Oliviero, junto ao Curso de Direito da Università degli Studi di Perugia. Coorientador do módulo de Direito Transnacional no curso de Direito Público Comparado.

\section{ABSTRACT}

Objective: The objective of this paper is to expose some consequences of the economic globalization process - as well as of the recent "sovereign debt crisis" - on the normative enforcement of workplaces' health and safety.

Methodology: The methodology used is based on bibliographic and legislation research, as well as on doctrine and articles published in specialized journals.

Results: It is concluded that after the Lisbon Summit of 2009, the whole matter of fundamental rights in the European Union has taken a new connotation. Local economic interests and social protests - in opposition to the "neoliberal agenda" of EU institutions - have played an important role in stopping the enforcement of the "Constitutional Treaty" and boosted an anti-Euro mobilization. In the meanwhile, the 
European bodies and transnational corporations have continued to settle a new and alternative basis for the integration. A radical shift can be observed, from the research of synthetic set of principles - as those established on the EU Charter of Fundamental Rights - to a deeply technical and detailed normative production. The regulation on safety and healthy workplaces is one of the best point of view to study this change. Far from calling into question the unbalanced positions between the parties in contemporary labour relationships, the European strategy for workers' protection move through procedural issues and voluntary obedience to the soft law instruments. In the past, the legal doctrine described the creation of a multilevel architecture of institutions, sometimes implemented in a top-down approach. Along with this, recently, it was implemented the establishment of common organizational standards associated to a specific system of corporate governance to pursue a better integration between business and fundamental rights.

Contributions: The main contribution of this study relates to the interdisciplinary approach, which has been carried out by means of a deep and careful study of "soft" law documents, i.e. the best practices, strategies and communications and a focus on how they can affect the enforcement/interpretation of the traditional sources of "hard" law.

Keywords: Social rights; occupational health and safety; corporate governance; hard Law and soft Law; European Law.

\section{RESUMO}

Objetivo: O objetivo deste artigo é expor algumas consequências do processo de globalização econômica - bem como da recente "crise da dívida soberana" - na aplicação normativa da saúde e segurança dos locais de trabalho.

Metodologia: A metodologia utilizada é baseada em pesquisas bibliográficas e legislativas, bem como em doutrinas e artigos publicados em periódicos especializados.

Resultados: Conclui-se que, após a Conferência de Lisboa de 2009, toda a questão dos direitos fundamentais na União Europeia tomou uma nova conotação. Os interesses econômicos locais e os protestos sociais - em oposição à "agenda neoliberal" promovida pelas instituições europeias - têm desempenhado um papel importante em parar a execução do "Tratado Constitucional" e impulsionar uma mobilização anti-Euro. Neste interim, os organismos europeus e as empresas transnacionais instalaram uma base nova e alternativa para a integração. Uma mudança radical pode ser observada a partir da pesquisa de um conjunto (ainda) sintético de princípios - como os estabelecidos na Carta dos Direitos Fundamentais da União Europeia - para uma produção normativa profundamente técnica e 
detalhada. A regulação da segurança no local de trabalho é um dos melhores pontos de observação para estudar a transformação mencionada. Longe de pôr em causa as posições desequilibradas entre as partes nas relações de trabalho contemporâneas, a estratégia europeia para a proteção da saúde dos trabalhadores prefere as questões procedimentais e a adesão voluntária aos instrumentos de soft law. No passado, a doutrina jurídica descrevia a criação de uma arquitetura multinível de instituições, àss vezes implementada por meio de uma abordagem de cima para baixo (top-down approach). Junto com isso, recentemente, houve a implementação de padrões organizacionais comuns para a instituição de um sistema específico de governança corporativa que busca uma melhor integração entre os negócios e os direitos fundamentais.

Contribuições: A principal contribuição deste estudo refere-se à abordagem interdisciplinar, realizada por meio de um estudo profundo e cuidadoso de documentos de soft law (lei não vinculativa), i. e, boas práticas, estratégias e comunicações, e um foco em como elas podem afetar a aplicação / interpretação das fontes tradicionais da hard law (lei vinculativa).

Palavras-chave: Direitos sociais; segurança e saúde ocupacional; governança corporativa; hard Law e soft Law; Direito europeu.

\section{INTRODUCTION}

This paper aims to expose some consequences of the economic globalization process - as well as of the recent "sovereign debt crisis" - on the normative enforcement of workplaces' health and safety.

The research path has started from the current complexity of normative production provoked by the establishment of new ruling subjects. So, for example, in the Italian territory must be recognized three institutional levels which are: a) the International bodies and the European Union; b) the national Parliament; c) the Regional Council and local municipalities in each Region. The intrinsic diversity between those bodies emerges - as we will show - in the contrast between the "pragmatic attitude" adopted by the European institutions, on one side, and the Member States' defence of government control of social issues, on the other.

While the research was developing, it has immediately appeared critical the ideological pressure of global competition, for which the right to health represents, 
firstly, a "spending factor" for public authorities and private companies. That called for the adoption of an interdisciplinary approach, which has been carried out by means of a deep and careful study of "soft law" documents - i.e. the "best practices" promoted by the International Labour Organization (ILO) or the E.U. «strategies» and "communications» - and a focus on how they can affect the enforcement/interpretation of the traditional sources of ("hard") law. As it has been recently remarked by Scarciglia $(2015$, p. 45$)$ :

From a global point of view, there are new factors in comparative studies, such as the emergence of new spheres of normativity, private powers and transnational actors in an international arena, a new configuration of political relations, and a criticism of the Western view of the relationship between the centre and periphery. To this element - defined "impact" or "enmeshment between the global and the local", it is necessary to add those of extensity, intensity and velocity, as traits of globalization, opening up new frontiers in the comparative law scholarship.

Each level has been subject to a separate study in order to determine the main differences as well as the possible connections. For example, the International and European regulatory framework is an essential starting point in this research, both for the matters of legal and political theory linked with the integration process and for the consequences of the annexation of former Soviet countries to the common market. It can be noted, indeed, that the two aspects are strictly intertwined, as the constitutional recognition of the International and European Law primacy formalized in Italy by the Article 117 of the Constitution, reformed by the Constitutional Law no. 3, dated October $18^{\text {th }}, 2001$ - cannot be dissociated from the needs to standardize production techniques and adjustment of the Old Continent's single market. The same process of "constitutionalization» of International and European Law's primacy has interested the various Member States, even if in different degrees (CASSESE, 2009). Notwithstanding the financial crisis, the economic growth still represents the keystone of the European integration and social policies which are part of the development plans of the market. The EU Strategic Framework on Health and Safety at Work, adopted by the Commission in 2014, states that: 
Risk prevention and the promotion of safer and healthier conditions in the workplace are key not just to improving job quality and working conditions, but also to promoting competitiveness. Keeping workers healthy has a direct and measurable positive impact on productivity and contributes to improving the sustainability of social security systems (EU COMMISSION; 2014, p.2).

Health services represent a "field for investment", as it is generally assumed that their functioning cannot be supported by the only public budget anymore. The challenge posed by the financial crisis on the sustainability of the welfare states requires from the national authorities some considerable reforms, which are going to be implemented in a narrower range of practicable policy options. It has been observed a multilevel protection of Social Rights coming into place in a "onedimensional process of development", where legal pluralism inevitably finds its "unity" in the financial viability of the political choices. This is one of the most dangerous field for European integration, as it is made clear by the EU Commission Staff Working Document, "Investing in Health" (EU COMMISSION, 2013, p. 2):

Health is an important part of public budgets. It represents almost a third of social policy budgets. Public expenditure accounts for almost $80 \%$ of healthcare budgets. In 2010, public spending on healthcare accounted for almost $15 \%$ of all government expenditure.

Furthermore, the increasing fragmentation of the production chain, typical of the post-Fordist industrial relations, determines the "atomization" of the corporate management and planning. However, this complexity at "high level" does not correspond to a diversification of the working processes, but rather in their simplification and de-qualification (CASTELLS, 2002). In that sense, the growing call for a "continuing professional education" rather than an investment on the corporate human resources expresses a simpler need to comply with the new technical standards (DI NUNZIO, 2012, p.177). Nevertheless, every optimization of the logistics and production cycle usually brings new problems concerning the enforcement of basic requirements relating to the health of workers. This explains both issues, why international bodies for standardization have promoted new models 
for corporate organization and their progressive reception by the national normative authorities.

\section{INTERNATIONAL STANDARDS FOR WORKPLACE SECURITY: THE BS OHSAS 18001}

Economic reasons certainly may offer justification to a (formally) voluntary adoption of transnational "best practices" on occupational health and safety management. However, it may be equally important to underline the main plausible consequences of this new approach. From a purely legal point of view, this process may determine a decrease of the public role of regulation in favour of private arrangement and a consequent raise of employers' and workers' trade union commitment in guaranteeing a safety workplace. In bigger companies, however, even the adhesion of leaders of trade unions would not avoid a centralization of risk management policies decisions at the expenses of the workers' participation provided, for example, in the Italian legislative Decree no. 81/2008 and in the European Directive no. 89/391 (HAUERT \& GRAZ, 2014, p.16).

The private adjustments of workplace security are currently inspired by the British Standards Occupational Health and Safety Management Systems Requirements, officially called BS OHSAS 18001. It was incorporated in 1999 to fulfil the need of harmonization among the existing national standards: the new management system had initially obtained the approval of 14 national standard organizations and - after the 2007 reform - it has been enforced in 116 countries. Notwithstanding the global spread, this model has been criticized due to its "legalistic approach" (FRICK \& KEMPA, 2011): in other words, it aims mainly to comply normative requirements, rather than considering the "whole" productive process - inhouse and outsourced - and detect specific health risks not contemplated. As a consequence,, in 2001 the International Labour Organization promoted the Guidelines on Occupational Safety and Health Management Systems (ILO-OHS 
2001) as an attempt to adjust the effects and legitimize the adoption of private standards. ILO-OHS 2001 promotes a "pragmatic approach" to occupational safety: it contemplates, firstly, a constant monitoring of OHS enforcement of choices and secondly the possibility of a review based on the monitoring results. In a broader perspective emerges a specific attention to stakeholders' participation, both in monitoring and decisional activities - even if most of the time it is not intended as "all workers", but, rather, "their OHS representative" participation.

\section{A "SOFT APPROACH" TO THE PRIVATIZATION OF WORKPLACE SAFETY: STRENGTHENING THE STAKEHOLDERS' COOPERATION IN OCCUPATIONAL HEALTH AND SAFETY}

The International Labour Organization (ILO) and the World Health Organization (WHO) are the most active international bodies in the health protection of workers policy-making. Their action consists essentially in the creation of an efficient, flexible and globally enforceable safety and health framework. Even before the European Community directive no. 89/391, Article 4 of ILO Occupational Safety and Health Convention of 1981 provided a generic preference for "prevention policies", which shall be implemented "by minimizing, so far as is reasonably practicable, the causes of hazards inherent in the working environment».

Along twenty-five years the purpose of ILO has been to develop a "culture of prevention", built on workers continuous formation/information, based on accidents data collection in each working sector and territory with the advise and cooperation of trade unions. Such elements compose the contents of ILO Promotional Framework on Occupational Safety and Health Convention (C-187/2006) signed in 2006 but enforced in 2009. The Member States are asked to plan their action according to a "prevention policy", following principles and criteria posed in Articles 3, 4 and 5. Furthermore, according to ILO, national strategies need specialized authorities to effectively carry out information and data collection tasks and health services 
specialized in professional safety with full investigative powers - also inside the workplace - (Article 4, para.. 3, "a", "b", "d" and "f") C-187/2006). The National Health service shall «promote, at the level of the undertaking, cooperation between management, workers and their representatives as an essential element of workplace-related prevention measures" (Article. 4, para. 2, "d") C-187/2006). The ILO regulation provides a "multilevel" mechanism of health and safety framework implementation, whereby the legislation of Members States concur with company governance in order to extend the decision-making process to all personnel. A similar trend has been observed in other contexts, where the attempt to improve the working condition has been developed through a top-down approach (PAFFARINI, 2014).

Another fundamental contribution sourced by ILO refers to the private organizational standards having such a wide spread. The "best practices" - often stated in not-binding acts - are fundamental as they offer a clear and simply-imitable example of risk prevention. Moreover, due to the moral inducement in view of the prestige of the institution, any different choice should be justified. The «Guidelines on Occupational Safety and Health Management System», briefly called ILO-OSH 2001, are the most prominent example emanated in 2001 by the technical body of ILO the International Labour Office of Geneva - they have been settled with the contribution of trade unions of workers and employers, governments and acknowledged stakeholders.

As stated in the Introduction of the Guidelines, it is an instrument available «by all those who have the responsibility for occupational safety and health management», who are as per ILO policy the employers and the manager. In order to provide a useful support, the Guidelines separate the different moments which form an occupational safety and health (OSH) framework: "policy»; "organizing»; «planning and implementation»; «evaluation» and «action for improvement».

The Guidelines first require that the company «policy» shall be «appropriate» with reference to the «size», the «nature» of the activity and the infrastructure of the workplace (para. 3.1). In order to assure a full adaptability and efficiency, it is stressed the importance of the «worker participation», which is "an essential element 
of the OSH management system in the organization» (para. 3.2). It is possible to perceive a proposal for a "self-restraint attitude", from the national parliament, which should leave enough space for choices at "lower level", especially when those are the outcome of an "open" and "apparently global" dialogue among the workplace actors. For this purpose the management should support «the establishment and efficient functioning of a safety and health committee", as well as «the recognition of safety and health representative of the workers, in accordance with national laws and practice» (para. 3.2.4). The company «organization» shall permit the immediate and exact identification of responsibilities at all levels: the personnel and the elected representatives should be constantly informed of any change on the OSH staff (para. 3.3.2). Upon its existence, it should be ensured «effective arrangements for the full participation of the workers and their representatives in the safety and health committees» (para. 3.3.2, " $k$ "). The Guidelines conceive «documentation» as a part of the company organization: an $\mathrm{OSH}$ archive should maintain all the acts and materials concerning policy, allocated responsibilities for the implementation of $\mathrm{OSH}$ management system, main hazards/risks in the workplace, as well as arrangement for their prevention and control (para. 3.3.5). On the other hand, ILO promotes the establishment of a record activity in every workplace - accessible to the workers and their representative, "while respecting the need for confidentiality» - which should collect work-relating injuries and diseases data, report on workers' exposures, surveillance of working environment and «results of both active and reactive monitoring" (para. 3.5.4-5). The "planning and implementation» of $\mathrm{OSH}$ management system is divided in two steps: firstly the «initial review» and secondly the effective prevention. The employer and the competent personnel provide a recognition and exam of each company workplace hazards to be compared with the national laws, regulation, guidelines, «voluntary programs and other requirements to which the organization subscribes» (para. 3.7.2). The results obtained are used to plan new measures to achieve the required safety standards.

As a last perspective, the requirement of the Guidelines for the establishment of «measurable $\mathrm{OSH}$ objectives», such as providing adequate human and financial 
resources, testifying how the most important international bodies are unanimously promoting a «problem solving approach» in topics of fundamental rights (Paffarini, $2015,171)$. The ILO guidelines provides for such reason a further «evaluation» step, which should be carried out on a regular basis in order to adopt the pertinent system reforms. The record of activities should be followed by the statistical elaboration of data, identification of a performance due to the observation of improvements and mistakes (para. 3.11.5). The statistics should make possible the recognition of causes of accidents and professional diseases: if necessary, the employer and the competent personnel with the appropriate participation of workers and their representatives should carry out investigations to discover the origin and the underlying sources of danger (para. 3.12 - 3.13). The "action for improvement", which closes the ILO scheme of management depends on the correct identification of the problems that make the organization not reaching the standards. This final step is conceived as a "re-start" of the circle: a new policy for a new organizational framework to be implemented and evaluated again.

Although they are not binding, the innovative statements introduced with the ILO Guidelines have been decisive for the following development of private OHS standards. In particular, the rejection of unilateral policies in workplace safety gained a wide agreement and pushed the British Standard Institute to reform the OHSAS 18001 in 2007. Furthermore, after the introduction of stakeholder participation mechanisms inspired by ILO-OHS 2001, both national and international authorities have reviewed their position toward the standard. The Italian legislator, for instance, recognized by way of Article 30 of the Legislative-Decree no. 81/2008, that OHSAS 18001:2007 comply with national legal requirements on the organizational framework of the company and introduced a "presumption of compliance" in favour of the companies which submit that standard1.

Besides some relevant effects on employer's accountability - such as discharging responsibility deriving from administrative law - the legislative reception

1 «In sede di prima applicazione, i modelli di organizzazione aziendale definiti conformemente alle Linee guida UNI-INAIL per un sistema di gestione della salute e sicurezza sul lavoro (SGSL) del 28 settembre 2001 o al British Standard OHSAS 18001:2007 si presumono conformi ai requisiti di cui al presente articolo per le parti corrispondenti». 
of international standards ended a complex debate about the different intensity of (national) legislative and (transnational) private autonomy models. Nowadays, the OHSAS 18001:2007 is almost universally accepted as a lawful standard - in the mean of legally accurate - and there is no means for companies to ask for improvement to the private society of standardization - as the British Standard Institute.

The private certification is actually an authentic "market" which origins should be traced in the lack of clearness which normally characterized OHS national legislations. The growing demand for simplification, certainty of obligations on infrastructure and working process preventive measures opened an international competition among standardization societies in order to create a flexible and adaptable organizational system. The more the standard is expected to guarantee any discharge in case of accident and professional disease, the better is its rating in the certification market. It is possible to distinguish two main aspects in the development of private risk management systems. First emerges the ability of international bodies to create global standards and the good outcome of a raising level of protection - especially in developing countries. However, it shall be intuitive the lack of interest in any improvement - in the sense of raising the workers' safety after the legal recognition of those private frameworks by the national authorities. Advancements will be introduced with credibility to improve the flexibility or the costefficiency, rather than for raising levels of health protection. Finally, it would be wrong to believe that this problematic concerns only big enterprises: the SME are the most exposed - because of their dimensions and financial resources - to the negative consequences of a bad, unclear or "just" complex legislation. For this purpose they are the main consumers of OHS certifications.

The market dynamics create labour law models which, despite their initial innovative purpose, reach their limits in the market demand itself. It will be interesting to follow the future development of such process of legal reception after the approval of parliamentarians considering the case-law and the local bargaining evolution. 
The "legal status" of OHS management models depends also on the moral persuasion consciously carried out by some important bodies, like the World Health Organization (WHO) which has recently made an important acknowledgement of health management systems. According to this document, the Member States have the duty to ensure «healthy work practice and work organization» (para.13), which includes explicitly the adoption of "basic set of occupational health standards" recognized in international level (para.12). Actually, the WHO has become a proper stakeholder in global tendency only by providing guidelines and promoting the already existing and ILO-recognized standards for workers' protection..

\section{SOCIAL ACCOUNTABILITY STANDARDS AND WORKPLACE SAFETY: ETHICAL CONSUMERISM IMPROVING WORKING CONDITIONS?}

A further step in adopting self-ruling parameters on safety workplaces has been made with the EU Corporate Social Responsibility Program - CSR ${ }^{2}$, to which any business enterprise (also in the service sector) can access voluntarily. The program requires the adaptation to a series of regulatory profiles, among which some relating to safety and health in the workplace.

The idea that business corporations can undertake a social commitment has been promoted in the first instance by the NGOs to keep global competition into "ethically justified level". This pressure has been brought to include in the companies' policies the adoption of certain organizational frameworks allowed by the international bodies of standardization as "socially and environmentally sustainable". However, this trend would not have been possible without the growth, especially inside Western countries, of a "critical consume", which at present is the main supporter of the companies that are participating in the program.

The concept of "Corporate Social Responsibility» has been outlined several times by the European institutions. In particular there are four documents providing

${ }^{2}$ The general information page is available at the website: https://bit.ly/1RvcrxW 
the best definitions, all of them belonging to the soft law area ("Communications from the Commission to the European Parliament»). The first document is reported in the «Green Paper» titled "Promoting a European framework for corporate social responsibility", on which is stated that "being socially responsible means not only fulfilling legal expectations, but also going beyond compliance and investing "more" into human capital, the environment and the relations with stakeholders" (para. 21). «Companies, governments and sector organizations are increasingly looking at additional ways of promoting health and safety, by using them as a criterion in procuring products and services from other companies and as a marketing element for promoting their products or services» (para. 32). In a following document - COM (2002) 347 - it has been highlighted the "global nature of CSR issues and concerns, reflecting the fact that a growing number of enterprises, including SMEs, are developing their business world-wide, as they take advantage of market liberalization and trade integration and are sourcing from subsidiaries and suppliers in developing countries» (para. 3). Later, the Commission returned to the issue of CSR - COM (2006) 136 , expressing the aim to create in the territory of the Union a centre of cutting-edge programming in social and environmental responsibility and, above all, to reaffirm that European companies should enforce CSR principles everywhere they carry on their business, «in Europe and globally» (ph. 3). Finally, in 2011, the concept has been reviewed: the CSR has been identified with «the responsibility of enterprises for their impacts on society" - COM (2011) 681, para. 3. Furthermore, the Commission affirms the "multidimensional nature» of the concept, as it takes into account several "key point" of the productive activity, such as workers human rights (among which it also includes the right to a healthy workplace), environmental issues and anti-corruption struggle (para.3.3).

The voluntary measures introduced by the CSR can be considered an integration of the rules of public authority, as they likewise aim at promoting a culture of prevention - in other words, a better level of safety and health protection at workplace. The reference standard is the Social Accountability 8000 International Standard (SA 8000), which was first elaborated in 2008, but in 2014 was object of a 
new version. It contains technical rules on several aspects chosen by the experts of Social Accountability International (SAI) - a multilateral organization whose membership includes the European Union and most of the industrialized Nations which conducted a study of the more complex elements regarding the relationship between civil society, environment and enterprises. The text elaborated gives a great attention to "definitions» (section III), while the fourth section is dedicated to the descriptions of procedure and management required to gain the certification of "social responsibility». Those are divided in nine points, each-one containing the own set of "criteria»: child labour; forced and compulsory labour; health and safety; freedom of association and right to collective bargain; discrimination; disciplinary practices; working hours; remuneration; management system.

Beyond the fact that most of the "criteria" have recognized the existent international standards promoted by the UN and ILO treaties, what is really interesting on the SAI document is the corporate governance system described in the last section. In particular, the attempt to rise as much as possible the number of stakeholders which take part in the decision-making process. In this sense, the ninth point outlines a management system - based on the objectives defined by the first eight sections of the SA 8000 - whose main profiles are modelled on the pattern of the ILO OHS Guidelines. It is grounded on the "continuous improvement» principle (enforced by the scheme: «Plan - Do - Check-Act»), with some obvious differences related to the monitoring parameters and the issues for consultation of audits: in both cases are embedded instances of CSR. It should be noted that the objective of the SA 8000 is to consolidate and possibly expand the area of the "ethical consumerism". This aspect determines some special characters of the management system, i.e., control on suppliers/subcontractors and sub-suppliers - with respect to which the company shall make a reasonable effort to ensure that the requirements of this standard are fulfilled also on their part (9.10) - and the extension of participation in the monitoring activities to parties outside the company - unions, suppliers, buyers, non-governmental organizations, local government officials and national - which are considered "interested parties" (9.4). 
The third section is dedicated to the issue of safety and health at work: it is articulated in nine sections exposing the standards for each aspect involved. The guarantee of a healthy environment shall be achieved by minimizing «the causes of all hazards» by using the technological knowledge available at the time (3.1); this responsibility falls on the entrepreneur or representative who has the leadership in charge of a given environment (3.4). Every worker shall receive specific health and safety information and training (3.6) whose effectiveness will be greater if measured according to the identified risks and potential, as well as documentation on the past incidents that the company must keep (3.7). The company must provide all the tools and personal protective equipment, providing the appropriate training to use to workers (3.3). Furthermore, shall be ensured the presence of drinking water and an adequate hygiene in all the facilities available to the workers - especially the toilets and dormitory (3.8 and 3.9). The last prevision recognizes to «all personnel» the right to leave the workplace without seeking permission of the company management, in case of «imminent and serious danger» to the health (3.10).

Safety and health protection provisions are contained also in the remaining sections, as there are other aspects of the corporate policies in which they are likely to be involved. There is no doubt - for example - that the prohibition of child labour (Sec. 1.1) protects the person's physical and mental health growth. The same purpose with a more specific focus has the permission to the work of young workers subjected to compulsory education laws on condition that the total daily time spent at school, transport and work do not exceed 10 hours - «and in no case shall young workers work more than 8 hours a day» (1.3). From another point of view, health protection come into consideration if analyzing the discipline of «working hours" (Sec. 7): in particular it complies this need with the provisions which limit «the normal work week» to a maximum of 48 hours (7.1) and order «one day off following every six consecutive days of working" (7.2). Corporate needs cannot prevail on workers personality: any personnel shall be forced to overtime work and in any case it shall exceed 12 hours or be requested regularly (7.3). However, there is a critical aspect represented by the final provision of this section (7.4), as it opens to possible 
exceptions when it is «freely negotiated in a collective bargain agreement» in which is represented «a significant portion» of the corporate workforce. In other words, by alleging an unexpected «business demand» or other productive circumstances, the corporation managers may legitimately demand extra-working-time if workers' trade unions agree. This "deregulation case" shows that it is quite inopportune introducing a voluntary standard in promotion of corporate social responsibility and providing an "exit strategy" at the same time (even if legitimized by trade union signature). Such a consideration should be even more effective on working-time limits - especially overtime-work - where health and safety are strongly involved, perhaps more than in other issues. How not considering - for example - that «stress», "depression» and «anxiety» are the second health problems in the workplaces as it was demonstrated by the recent survey of the Commission "Evaluation of the European Strategy on Safety and Health at Work 2007-2012'?

\section{CONCLUSION}

This study has been prepared for purpose of highlighting new trends on OHS protection, revealing the economic ratio which has given origin to new legal models, stressing the limits of those in terms of guaranteeing an effective - in the means of "well-informed" and "wide-spread" - workers' participation. At the end of this brief research the first out-coming impression concerns the contradiction of a growing standardization of workplaces' safety framework in the context of an extreme flexibility of workers contractual status inside the companies (WELLS, 2006; PAFFARINI, 2017). In particular, a shorter duration of contract or a multiplicity of tasks may not affect the physical health, but they certainly increase anxiety as well as a constant concern inside and outside the workplaces. A new approach on matters of workers' participation or evaluation of risks should take into account the growing number of work-related mental diseases. 
From another perspective, the continuous transformation of labour relations demands a serious theoretical approach to the matter of legal pluralism in order to resolve the uncertainty that raises from the multiplication of regulatory systems (LOCCHI, 2014). It is necessary to acknowledge that the old archetype of "worker" has been erased by the global competition - especially in the Western Countries -, while even small and medium enterprises reveal an extreme variety of labour relationships. The generalization of the outsourcing frameworks - which has extremely boosted this trend - represents one of the main threat for the effectiveness of OHS policies for several reasons. First, as the workers are no longer directly employed by the main corporation and the outsourcing depends on the productive or logistic needs of the latter, it is intuitive to assume a request for flexibility on working time and tasks. Second, according to the World Health Organization Global Plan of Action 2008-2017 (para. 16), the lower budget and lesser human resources explain why the small and medium enterprises - which are normally the "outsourcee" - have the higher percentage of accidents and professional diseases. Finally, the identification of OHS responsibility could be more complex and for sure different kinds of frauds (fiscal, civil and, sometimes, criminal) may be facilitated throughout outsourcing.

As it has been already noted, carrying out legal studies on transnational rules, policies or voluntary systems for human rights protection needs, firstly, a recontextualization of legal categories and, then, an anti-dogmatic approach. As Zumbasen (2012, p. 17) noted:

[...] the term "transnational" identifies an intricate connection of spatial and conceptual dimensions: in addressing, on the one hand, the demarcation of emerging and evolving spaces and, on the other, the construction of these spaces as artifacts for human activity, communication, and rationality, the term transnational is conceptual.

The international standards created by the certification companies and the Working Staff of the European Commission convey few statements about substantial aspects of the management systems risks, while they focus on problem-solving. But 
restraining the problem to the financial sustainability of social security systems is not enough for an appropriate implementation of workers' fundamental rights. There is no advantage in opening the OHS management systems to workers' participation if decisional powers have a narrow space for their expression.

International bodies as well as the EU should take the proper initiatives in order to move the question on the "human costs" of global completion and, finally, resume their early leading-role in the promotion of a common vision of human rights and democracy. As it had been highlighted by the Brazilian Human Rights doctrine:

The universality of human rights, as one wishes to propose, does not mean the absence of inquiry into what is (or becomes) meaningful to people, nor the eternal sacralization of its content. On the contrary, one asks and increases their effects to the world. This flexibilization, it should be noted, does not mean relativization, but it is openly debating what makes sense in the experience of existence and why it deserves our protection. ${ }^{3}$ (AQUINO, 2014, p. 46) (Our translation).

\section{REFERENCES}

AQUINO, Sérgio Ricardo Fernandes de. 0 direito em busca de sua humanidade: Dialogos errantes. Editora CRV: Curitiba, 2014.

BRITISH STANDARD INSTITUTION. BS OHSAS 18001 - Occupational Health and Safety Management (OHS). BSI, 2007. Available at: <https://bit.ly/2JybTwT> (Last visited: June, $\left.10^{\text {th }}, 2018\right)$.

CASSESE, Sabino, I tribunali di Babele. I giudici alla ricerca di un nuovo ordine globale, Roma: Donzelli, 2009.

CASTELLS, Manuel. La nascita della società in rete, Milano: Egea, Università Bocconi, 2002.

ITALIA. Constitution (1948). Constitutional Law no 3, October $18^{\text {th }}$, 2001. Gazzetta Ufficiale, Rome, no. 248, p.3-9, October, 24th, 2001. Available at: $<$ https://bit.ly/2JO04BO $>$ (Last visited: June, 10 ${ }^{\text {th }}, 2018$ ).

\footnotetext{
${ }^{3}$ Original text in Portuguese: "A universalidade dos Direitos Humanos, como se deseja propor, não significa a ausência de indagação sobre o que é (ou se torna) significativo às pessoas, tampouco a sacralização eterna do seu conteúdo. Ao contrário, indaga-se e ampliam-seseus efeitos ao mundo. Essa flexibilização, adverte-se, não significa relativização porém, debater, abertamente, o que tem sentido na experiência do existir e porque merece a nossa proteção."
} 
. Legislative-Decree n.81, April, the $9^{\text {th }}$ of 2008. Gazzetta Ufficiale, Serie Generale no.101, April, the 30th, 2008 (Suppl. Ordinario n. 108). Available at: $<$ https://bit.ly/2m3SCUy $>$. (Last visited: June, 10 ${ }^{\text {th }}, 2018$ ).

DI NUNZIO, Daniele. Modelli organizzativi, sistemi di gestione della salute e sicurezza e benessere dei lavoratori. Questione giustizia, Roma, n. 2, p. 177-192, 2012. Available at: $\langle$ https://bit.ly/2LHuO4J $>$.

EUROPEAN UNION. Council Directive 89/391/EEC of 12 June 1989 on the introduction of measures to encourage improvements in the safety and health of workers at work. Official Journal of Law, no. 183, June, $29^{\text {th }}, 1989$ P. $0001-0008$. CELEX: 31989L0391. Available at: <https://bit.Iy/2LKMInq $>$. (Last visited: June, 10 2018).

EUROPEAN UNION COMMISSION. Communication from the Commission to the European parliament, the Council, the European Economic and Social Committee and the Committee of the Regions on an EU Strategic Framework on Health and Safety at Work 2014-2020, no 332 (final). EurLex, Brussels, June, $6^{\text {th }}, 2014$, CELEX: 52014DC0332. Available at: $<$ https://bit.ly/2kVYTIQ $>$. (Last visited: June, $10^{\text {th }}, 2018$ ).

. "Investing in Health" Commission Staff Working Document, no 43 (final). EurLex, Brussels, February, the 20 th, 2013 , CELEX: 52013SC0043. Available at: $<$ https://bit.ly/2sJo9Qy>. (Last visited: June, 10 ${ }^{\text {th }}, 2018$ ).

. Evaluation of the European Strategy on Safety and Health at Work 20072012, no 202 (final report), issues on march, $15^{\text {th }}, 2013$. EurLex. Brussels, May $31^{\text {st }}$, 2013. Available at: $<$ https://bit.ly/1f9GKHg $>$. (Last visited: June, 10 ${ }^{\text {th }}, 2018$ ).

Promoting a European framework for Corporate Social Responsibility (Green Paper). EurLex, Brussels, July, 8 ${ }^{\text {th }}$, 2011, CELEX: 52001DC0366. Available at: $<$ https://bit.ly/2JugPmi>. (Last visited: June, $10^{\text {th }}, 2018$ ).

FRICK, Kay; KEMPA, Viktor. Occupational Health \& Safety Management Systems. When are they good for your health?, Brussels: ETUI, 2011.

HAUERT, Christope e GRAZ, Jean-Christope. Beyond the transatlantic divide: the multiple authorities of standards in the global political economy of services. Business and politics, n.1, vol. 16, p.113-150, 2014.

INTERNATIONAL LABOUR ORGANIZATION. Guidelines on occupational safety and health management systems (ILO-OSH 2001). International Labour Office, Geneva, 2001. Available at: <https://bit.ly/2sZlipX >. (Last visited: June, $\left.10^{\text {th }}, 2018\right)$. 
LOCCHI, Maria Chiara. Brief reflections on legal pluralism as a key paradigm of contemporary law in highly differentiated western societies. Revista Brasileira de Direito, no. 2, vol. 10, p. 74-84, 2014.

PAFFARINI, Jacopo. Fundamental rights and migration of judicial models in the conditionality of investment treaties and transnational public policies. The Cambodian case. Revista Brasileira de Direito, no. 1, vol. 10, p. 33-47, 2014.

Modelli costituzionali e società di mercato. Egacal: Lima (Perù), 2015.

. A Brazilian Outlook On The (Un)Sustainable Development Of Corporate Capitalism. Revista Jurídica Unicuritiba. Curitiba, v.3, n.48, p. 35-53, 2017.

SCARCIGLIA, Roberto. Comparative Methodology and Pluralism in Legal Comparison in a Global Age in Beijing Law Review, Beijing, no. 6, p. 42-48, 2015.

SOCIAL ACCOUNTABILTY INTERNATIONAL. Social Accountability 8000 International Standard. SAI, June 2014. Available at: <https://bit.ly/2t1cfkn $>$. (Last visited: June, $\left.10^{\text {th }}, 2018\right)$.

WORLD HEALTH ORGANIZATION, Workers' Health: Global Plan of Action 20082017 (WHA 60.26). WHO Publications, Geneva, April, 2013. Available at: $<$ https://bit.ly/2DvoxcJ $>$. (Last visited: June, 10 ${ }^{\text {th }}, 2018$ ).

WELLS, Don. "Best Practice" in the regulation of International Labor Standards: Lessons of the U.S.-Cambodia Textile Agreement. Comparative Labour Law and Policy Journal, no. 3, Vol. 27, p. 357-377, 2006.

ZUMBASEN, Peer. Carving out typologies and accounting for differences across systems: towards a methodology of transnational constitutionalism in ROSENFELD, Michel; SAJÒ, Andreas (edited by). The Oxford Handbook of Comparative Constitutional Law, Oxford: Hardback, 2012. 